\title{
FAUNA PRESERVATION SOCIETY FILM LIBRARY
}

The film library consists of the following $16 \mathrm{~mm}$. films and two $35 \mathrm{~mm}$. film strips. All are coloured unless otherwise stated. They may be borrowed by members and others.

\section{Silent Films (with Captions)}

"The African Elephant." 10 minutes.

"Wild Life in East Africa." 30 minutes.

"Wild Life in Southern Rhodesia." Elephants and other animals in the Wankie National Park, with a commentary. 15 minutes.

"Wild Animals of the Indian Jungle." 20 minutes.

"Foxes and Badgers." 11 minutes.

"Animals of Australia." 10 minutes, black and white.

"Wild Camels of Mongolia." 4 minutes.

\section{Sound Films}

"Kinship of the Creature." The animals of East Africa, with a plea for their conservation. 30 minutes.

"South Africa's Game Parks." A tourist film of the Kruger National Parks and the Hluhluwe Reserve. 16 minutes.

"Wild Life Sanctuary." A film of the Kruger National Park. 25 minutes.

"Expedition Moose." The protection of the moose in Ontario, Canada. 18 minutes.

"Ring-necked Pheasant." The life-history in Canada of the introduced ring-necked pheasant. 12 minutes.

"Heritage of Natal and Zululand." A tourist film of the Natal National Parks. 12 minutes.

"Wild Life in Uganda." 12 minutes.

"Stronghold of the Wild." East African animals and the work of the game departments. 35 minutes, black and white.

"Down in the Forest." Australia (Kangaroos). 6 minutes.

"Kaziranga." The wild animals of the Kaziranga Sanctuary, Assam. 12 minutes.

"Birds of East and Central Africa." 45 minutes.

\section{5 mm. Film Strip}

"Wild Life in East Africa." Twenty-five coloured pictures of animals, with a written commentary, suitable for an hour's talk. 


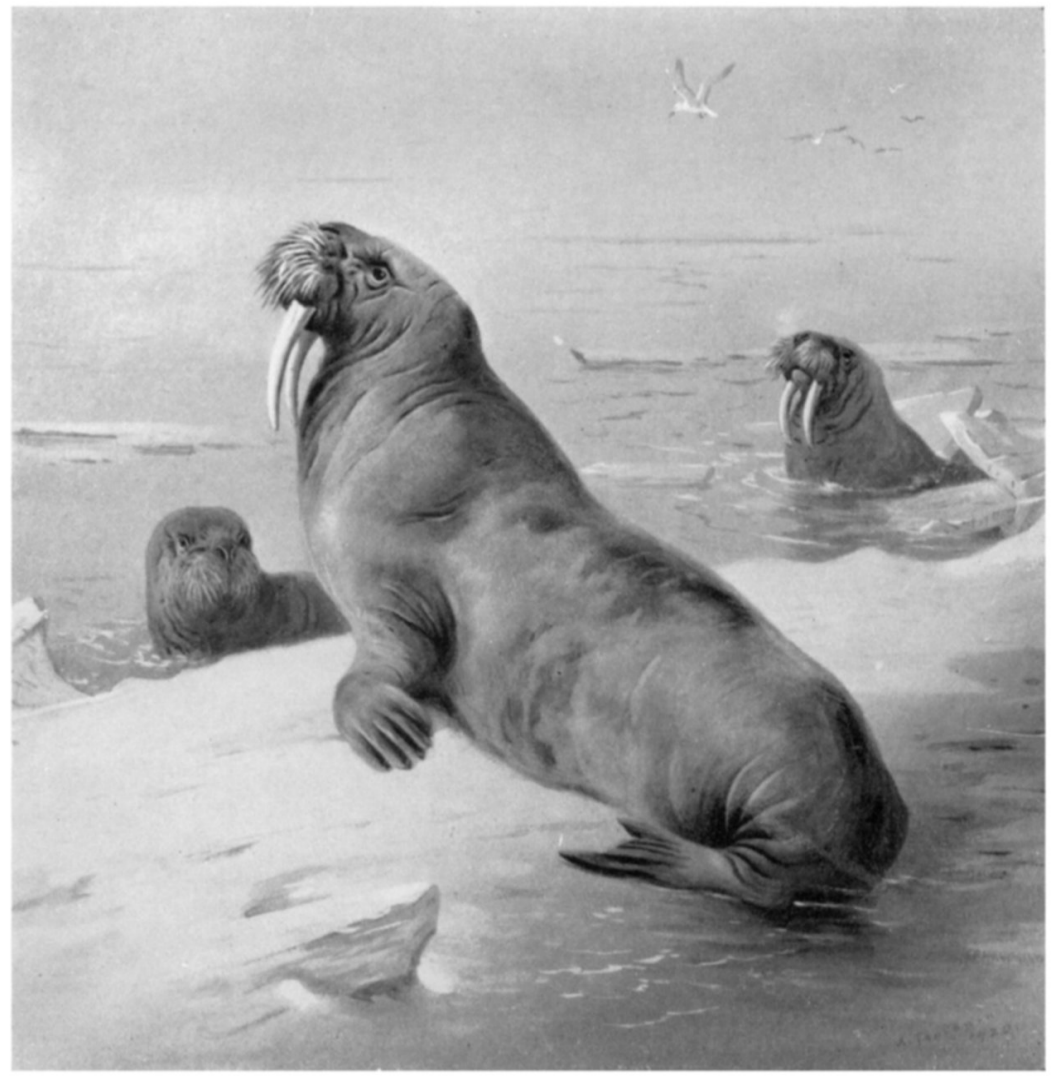

WALRUSES

BY ARCHIBALD TIIORBURN

(This picture, size 5. ${ }_{4}^{\prime \prime}$ by $4_{4}^{3 \prime}$ and in full colour, will be one of our 1961 Christmas Cards.) Reproduced by kind permission of $M$. Thorburn, Esq., The Glenbow Foundation, and The Tryon Gallery Limited. 


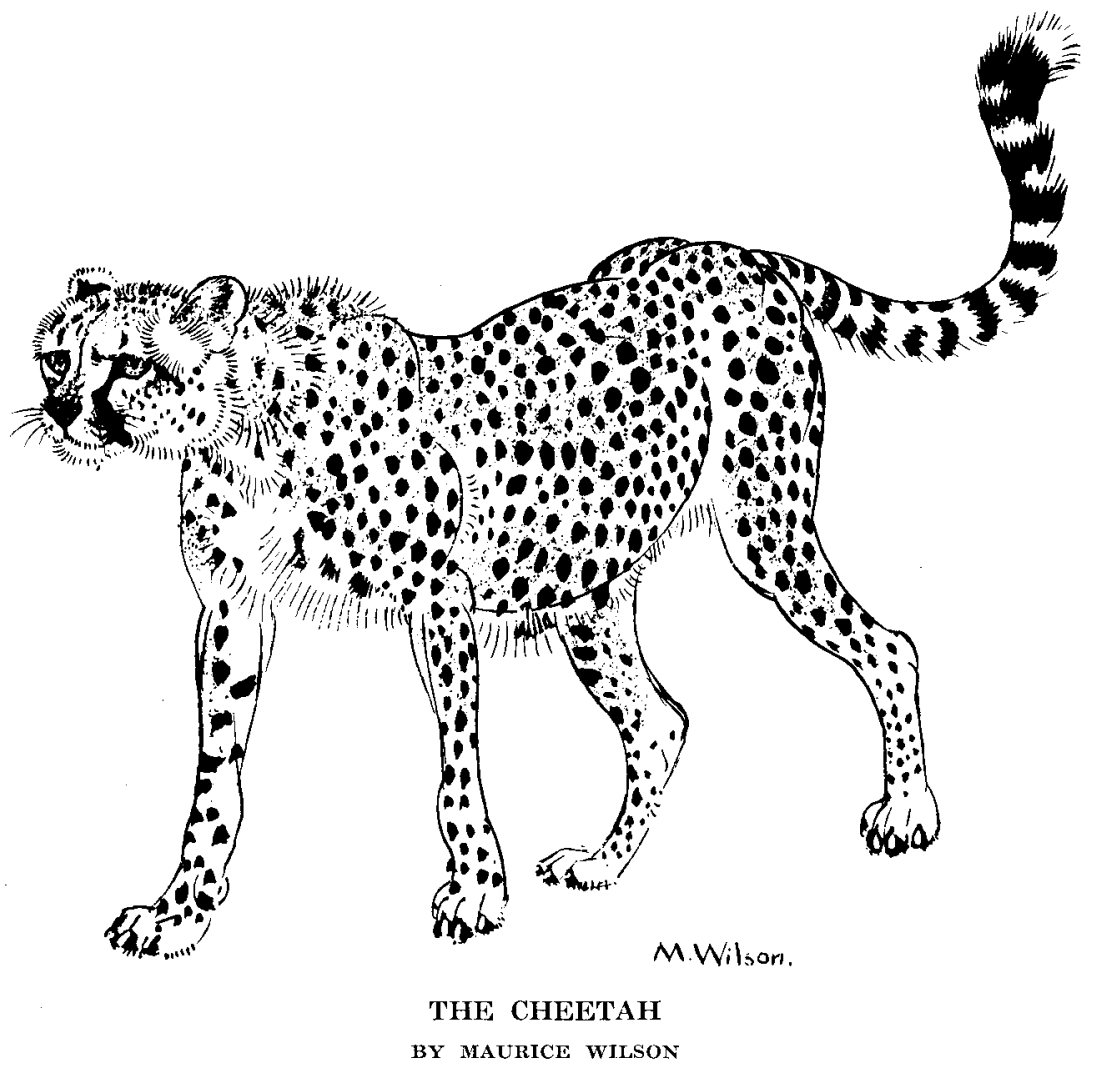

(This picture, reproduced by kind permission of The Observer, will be one of our 1961 Christmas Cards.) 